\title{
Karakteristik Demografi ODHA Di Papua
}

\section{Demographic Characteristics Of The People Living With HIV In Papua}

\author{
Mirna Widiyanti ${ }^{1}$, Moch Irfan Hadi ${ }^{2}$, Setyo Adiningsih' ${ }^{1}$, M Yusuf Alamudi ${ }^{3}$, Mei Lina Fitri Kumalasari ${ }^{2}$ \\ 1)Balai Litbangkes Papua \\ 2)UIN Sunan Ampel Surabaya \\ 3)AIRC Lab Professor Nidom Foundation \\ author1: ninawidhy@gmail.com ${ }^{1}$
}

DOI: http://doi.org/10.29080/jhsp.v3i1.175

\begin{tabular}{|c|c|}
\hline Kata Kunci & Abstrak \\
\hline $\begin{array}{l}\text { Karakteristik } \\
\text { Demografi } \\
\text { ODHA } \\
\text { Рариа }\end{array}$ & $\begin{array}{l}\text { HIV dan AIDS merupakan salah satu permasalahan di Indonesia. Berdasarkan data dari } \\
\text { Kementerian Kesehatan RI sampai dengan maret 2017, sebanyak } 407 \text { kota/kabupaten } \\
\text { dari } 507 \text { kota/kabupaten dan lebih dari } 87 \text { ribu orang mengidap AIDS. Berbeda apabila } \\
\text { dibandingkan dengan provinsi-provinsi lainnya, Papua mengalami epidemi HIV meluas } \\
\text { tingkat rendah dengan prevalensi HIV sebesar } 2.3 \% \text {. Jumlah penderita HIV lebih banyak } \\
\text { terjadi pada perempuan usia reproduktif dibandingkan pada laki-laki. Meskipun HIV } \\
\text { tersebar meluas di kelompok populasi umum baik untuk laki-laki maupun perempuan, } \\
\text { kegiatan seks komersial memberikan kontribusi yang besar terhadap epidemi di semua } \\
\text { wilayah Papua. Tujuan penelitian ini adalah menganalisis karakteristik demografi ODHA } \\
\text { Di Papua Sebagai Baseline Data Di Indonesia. Penelitian dilakukan di tiga wilayah di } \\
\text { Papua yaitu Kabupaten Nabire, Kab./Kota Jayapura, dan Kab. Jayawijaya dengan jumlah } \\
\text { responden sebanyak } 264 \text { orang. Dari hasil penelitian yang dilakukan didapatkan hasil } \\
\text { terdapat perbedaan karakteristik demografi ODHA di tiga wilayah Papua (Kabupaten } \\
\text { Nabire, Kab./Kota Jayapura, dan Kab. Jayawijaya). Dari hasil penelitian dibutuhkan } \\
\text { strategi penanganan ODHA yang berbeda di masing-masing wilayah. }\end{array}$ \\
\hline Keywords & Abstract \\
\hline $\begin{array}{l}\text { Characteristics } \\
\text { Demographics } \\
\text { People living With HIV } \\
\text { Papua }\end{array}$ & $\begin{array}{l}\text { HIV /AIDS is one of the issues in Indonesia. Data from ministry of Health of the republic of } \\
\text { Indonesia show untill march } 2017 \text { AIDS cases had been reported in } 407 \text { districts from } 507 \\
\text { districts in Papua province and accounted for more than } 87 \text { thousand cases of the people } \\
\text { living with AIDS. Comparing to other provinces in Indonesia, Papua provinces have low- } \\
\text { level generalized epidemic in which the prevalence of HIV accounts for } 2.3 \% \text {. The HIV } \\
\text { epidemic is more likely to be prevalent among women of reproductive age than men. } \\
\text { While, HIV spreads widely in the general population group for both men and women, sex } \\
\text { work contributes dominantly to the HIV epidemic in all regions of Papua. The purpose of } \\
\text { this study is to analyse the demographic characteristics of PLWHA in Papua as a baseline } \\
\text { data in Indonesia. The research was conducted in three regions in Papua, namely Nabire } \\
\text { Regency, District of Jayapura, and District of Jayawijaya with } 264 \text { respondents of study. } \\
\text { The research results showed that there were differences of demographic characteristics of } \\
\text { PLWHA in these regions of Papua. This result provide an insight that different appoaches } \\
\text { and strategies are urgently required to dealt with PLWHA in different regions. }\end{array}$ \\
\hline
\end{tabular}

\section{Pendahuluan}

HIV atau penyakit Human Immunodeficiency Virus adalah suatu jenis virus yang mengganggu fungsi sel darah putih pada tubuh manusia sehingga menyebabkan penurunan kekebalan tubuh. Penurunan kekebalan ini akan menyebabkan munculnya beberapa gejala penyakit yang berkembang menjadi penyakit AIDS (Acquired Immune Deficiency Sindrome).HIV/AIDS masih merupakan salah satu masalah kesehatan yang penting dan terus mengalami peningkatan sehingga menjadi permasalahan kesehatan di tingkat global.Pada tahun 2013 ditemukan jumlah kasus HIV baru sebanyak 1,5 juta kasus dengan rincian 1,3 juta kasus ditemukan pada usia dewasa dan 190.000 ditemukan pada anak yang berusia kurang dari 15 tahun $(1,2)$. 
Kawasan Asia Pasifik menempati urutan ketiga penderita HIV/AIDS terbanyak dengan jumlah 5,2 juta jiwa. Indonesia termasuk negara yang berada di dalam kawasan Asia Pasifik dan menyumbang angka sebanyak 620.000 jiwa penderita HIV/AIDS.Tahun 2015 di Indonesia ditemukan kasus HIV sebanyak 30.935 dan kasus AIDS sebanyak 9.215, namun pada tahun 2016 angka kejadian HIV mengalami peningkatan menjadi 41.250 kasus dan AIDS sebanyak 10.146 kasus. Jumlah terus meningkat pada tahun 2017 dengan jumlah kasus HIV sebanyak 48.300 kasus dan AIDS sebanyak 9.208 kasus (3).

Jumlah kasus penularan HIV tertinggi per kapita di Indonesia salah satunya adalah di Provinsi Papua dengan tingkat penularan sekitar 2\% dari jumlah penduduk dan ditemukan sekitar $7 \%$ penduduk yang berdomisili di pegunungan terinfeksi HIV.Provinsi Papua menduduki peringkat kedua penderita HIV terbanyak di Indonesia dengan jumlah 29.083 kasus dan peringkat ketiga penderita AIDS paling tinggi dengan jumlah penderita sebanyak 804 kasus. Jumlah penderita HIV di Papua terus mengalami peningkatan dari tahun ke tahun. Pada tahun 2015 terdapat 3.494 kasus dan meningkat menjadi 3.866 kasus di tahun 2016. Angka kasus HIV masih terus meningkat di tahun 2017 dengan jumlah 4.358 kasus(3).

Penyebab angka kasus HIV di Papua masih tinggi adalah karena akses pengobatan ARV dan dukungan serta penanganan yang masih terbatas.Walaupun sudah terdapat pelatihan staf dan perbaikan akses distribusi obat-obatan, namun obat yang disediakan masih berbayar dan penyediaannya tidak terusmenerus. Selain itu masih adanya informasi yang salah di wilayah pedalaman atau pegunungan(4).

Hambatan lainnya dalam pencegahan dan penaggulangan HIV/AIDS di Indonesia adalah adanya stigma dan diskriminasi yang masih tinggi terhadap ODHA.Stigma yang terjadi berupa sikap sinis, rasa takut yang berlebihan dan pengalaman negatif terhadap ODHA. Terjadinya penolakan terhadap ODHA oleh masyarakat membuat penderita harus hidup dengan menyembunyikan status penyakitnya sehingga stigma mempunyai dampak yang besar untuk kualits hidup ODHA dan penanggulangan HIV/AIDS $(4,5)$.

Hambatan-hambatan pencegahan dan penanggulangan tersebut dipengaruhi juga oleh beberapa karakteristik masyarakat, seperti pendidikan, usia, jenis kelamin dan suku budaya(6). Oleh karena itu, tujuan dari penelitian ini adalah untuk menganalisis karakteristik demografi ODHA di Papua sebagai baseline data di Indonesia.

\section{Metode Penelitian}

Jenis penelitian ini merupakan penelitian deskriptif kuantitatif dan dilaksanakan pada tahun 2017 dengan populasi adalah ODHA di Papua.Sampel diambil dengan metode random samplingdanberjumlah 264 responden.

Data demografi dikumpulkan melalui wawancara kepada subyek ODHA dengan menggunakan kuesioner. Prosedur pengumpulan data adalah dengan cara rekrutmen calon responden dilakukan oleh dokter dan perawat VCT sesuai dengan kriteria inklusi yang ditetapkan,dokter atau perawat VCT dan didampingi oleh peneliti atau teknisi dari Balai Litbang Biomedis Papua. Peneliti melakukan wawancara berdasarkan dokumen kuesioner yang telah dibuat dan kode register laboratorium yang tertera pada kuesioner digunakan sebagai kode spesimen biologis responden tersebut, data dimasukkan ke dalam template yang dibuat pada file .xls yang hanya dapat diakses oleh peneliti dan teknisi Balai Litbang Biomedis Papua. Kuesioner yang sudah terisi dengan data responden akan disimpan di lemari berkas terkunci yang aksesnya harus diketahui oleh Ketua Peneliti.Dibuat tabel distribusi frekuensi dari hasil data yang telah dikumpulkan.

\section{Hasil Penelitian \\ Karakteristik Responden}

Tabel 1. Data Jumlah Responden Penelitian

\begin{tabular}{llc}
\hline Kabupaten & Rumah Sakit/ Puskesmas & Jumlah Spesimen \\
\hline Nabire & PKM Bumi Wonorejo & 45 \\
& PKM St. Rafael & 45 \\
& & \\
& RSUD Yowari & 30 \\
Kab/Kota & RSUD Abepura & 24 \\
Jayapura & RSUD Jayapura & 30 \\
Jayawijaya & RSUD Wamena & 90 \\
\hline Total & & \\
\hline Sumber: & & 264 \\
\hline
\end{tabular}

Sumber: Data Primer, 2018 
Tabel 1 menunjukkan bahwa jumlah resonden yang datang ke klinik VCT adalah sebesar 264 ODHA yang berasal dari Kabupaten Nabire (90 ODHA), Kabupaten/Kota Jayapura (84 ODHA) dan Kabupaten Jayawijaya (90 ODHA).Klinik VCT tersebut berada di RSUD dan PKM.

Tabel 2.Karakteristik demografi ODHA di Kabupaten Nabire, Kab./Kota Jayapura, dan Kab. Jayawijaya

\begin{tabular}{|c|c|c|c|c|c|c|c|c|}
\hline \multirow[t]{2}{*}{ No. } & \multirow{2}{*}{\multicolumn{2}{|c|}{ Karakteristik Demografi }} & \multicolumn{2}{|c|}{$\begin{array}{c}\text { Kab. Nabire } \\
(n=90)\end{array}$} & \multicolumn{2}{|c|}{$\begin{array}{c}\text { Kab./ Kota } \\
\text { Jayapura }(n=84)\end{array}$} & \multicolumn{2}{|c|}{$\begin{array}{c}\text { Kab. Jayawijaya } \\
(n=90)\end{array}$} \\
\hline & & & $\mathbf{n}$ & $\%$ & n & $\%$ & $\mathbf{n}$ & $\%$ \\
\hline \multirow[t]{3}{*}{1} & Jenis Kelamin & & & & & & & \\
\hline & Laki-laki & & 31 & 34,4 & 34 & 40,5 & 45 & 50,0 \\
\hline & Perempuan & & 59 & 65,6 & 50 & 59,5 & 45 & 50,0 \\
\hline \multirow[t]{4}{*}{2} & Umur & & & & & & & \\
\hline & 17-35 tahun & & 67 & 74,4 & 45 & 53,6 & 62 & 68,9 \\
\hline & 36-55 tahun & & 21 & 23,3 & 36 & 42,9 & 27 & 30,0 \\
\hline & $>55$ tahun & & 2 & 2,2 & 3 & 3,6 & 1 & 1,11 \\
\hline \multirow[t]{8}{*}{3} & Pendidikan & & & & & & & \\
\hline & Tidak/belum pernah sekolah & & 9 & 10,0 & 5 & 6,0 & 25 & 27,8 \\
\hline & Tidak tamat SD/MI & & 8 & 8,9 & 3 & 3,6 & 11 & 12,2 \\
\hline & Tamat SD/MI & & 5 & 5,6 & 6 & 7,1 & 2 & 2,2 \\
\hline & Tamat SLTP/MTS & & 7 & 7,8 & 15 & 17,9 & 10 & 11,1 \\
\hline & Tamat SLTA/MA & & 33 & 36,7 & 38 & 45,2 & 20 & 22,2 \\
\hline & Tamat D1/D2/D3 & & 8 & 8,9 & 5 & 6,0 & 4 & 4,4 \\
\hline & Tamat PT & & 6 & 6,7 & 12 & 14,3 & 18 & 20,0 \\
\hline \multirow[t]{9}{*}{4} & Pekerjaan & & & & & & & \\
\hline & PNS/TNI/Polri/BUMN/BUMD & & 17 & 18,9 & 11 & 13,1 & 19 & 21,1 \\
\hline & Pegawai swasta & & 8 & 8,9 & 14 & 16,7 & 1 & 1,1 \\
\hline & Wiraswasta & & 7 & 7,8 & 13 & 15,5 & 11 & 12,2 \\
\hline & Petani & & 25 & 27,8 & 8 & 9,5 & 40 & 44,4 \\
\hline & Nelayan & & 0 & 0 & 0 & 0 & 0 & 0 \\
\hline & Buruh & & 0 & 0 & 0 & 0 & 0 & 0 \\
\hline & Lainnya & & 4 & 4,4 & 3 & 3,6 & 4 & 4,4 \\
\hline & Tidak Bekerja & & 29 & 32,2 & 35 & 41,7 & 15 & 16,7 \\
\hline \multirow[t]{4}{*}{5} & Status Pernikahan & & & & & & & \\
\hline & Belum Menikah & & 30 & 33,3 & 19 & 22,6 & 27 & 30,0 \\
\hline & Menikah & & 58 & 64,4 & 55 & 65,5 & 55 & 61,1 \\
\hline & Tinggal Bersama & & 2 & 2,2 & 10 & 11,9 & 8 & 8,9 \\
\hline \multirow[t]{3}{*}{6} & Suku/ Etnis responden & & & & & & & \\
\hline & Papua & & 80 & 88,9 & 45 & 53,6 & 86 & 95,6 \\
\hline & Non Papua & & 10 & 11,1 & 39 & 46,4 & 4 & 4,4 \\
\hline \multirow[t]{3}{*}{7} & Suku/ Etnis Ayah responden & & & & & & & \\
\hline & Papua & & 80 & 88,9 & 45 & 53,6 & 86 & 95,6 \\
\hline & Non Papua & & 10 & 11,1 & 39 & 46,4 & 4 & 4,4 \\
\hline \multirow[t]{3}{*}{8} & Suku/ Etnis Ibu responden & & & & & & & \\
\hline & Papua & & 80 & 88,9 & 45 & 53,6 & 86 & 95,6 \\
\hline & Non Papua & & 10 & 11,1 & 39 & 46,4 & 4 & 4,4 \\
\hline \multirow[t]{3}{*}{9} & $\begin{array}{l}\text { Suku/ Etnis Kakek dari } \\
\text { responden }\end{array}$ & pihak & Ayah & & & & & \\
\hline & Papua & & 80 & 88,9 & 45 & 53,6 & 86 & 95,6 \\
\hline & Non Papua & & 10 & 11,1 & 39 & 46,4 & 4 & 4,4 \\
\hline \multirow[t]{2}{*}{10} & $\begin{array}{l}\text { Suku/ Etnis Nenek dari } \\
\text { responden }\end{array}$ & pihak & Ayah & & & & & \\
\hline & Papua & & 80 & 88,9 & 45 & 53,6 & 86 & 95,6 \\
\hline
\end{tabular}




\begin{tabular}{lrrrrrc} 
Non Papua & 10 & 11,1 & 39 & 46,4 & 4 & 4,4 \\
& & & & & & \\
ku/ Etnis Kakek dari pihak Ibu responden & & & & & \\
$\begin{array}{l}\text { Papua } \\
\text { Non Papua }\end{array}$ & 80 & 88,9 & 45 & 53,6 & 86 & 95,6 \\
& 10 & 11,1 & 39 & 46,4 & 4 & 4,4 \\
ku/ Etnis Nenek dari pihak Ibu responden & & & & & \\
$\begin{array}{l}\text { Papua } \\
\text { Non Papua }\end{array}$ & 80 & 88,9 & 45 & 53,6 & 86 & 95,6 \\
\hline
\end{tabular}

Sumber: Data Primer, 2018

Karakteristik subyek dala penelitian ini terdiri dari umur, jenis kelamin, pekerjaan, pendidikan, status perkawinan, etnis responden dan dua generasi di atas responden, baik dari pihak ibu atau ayah responden. Tabel 2 menunjukkan bahwa responden di ketiga Kabupaten mayoritas perempuan dengan proporsi terbanyak adalah di Kabupaten Nabire (65,6\%). Jika dilihat dari kelompok umur, maka proporsi terbanyak adalah pada kelompok usia 17-35 tahun, dimana hal ini terlihat sama di ke 3 Kabupaten (Kabupaten Nabire 74,4\%, Kab./Kota Jayapura 53,6\%, dan Kabupaten Jayawijaya 68,89\%).

Pada tingkat pendidikan responden, proporsi terbanyak adalah lulusan SLTA/MA dimana hal tersebut terlihat sama pada 2 Kabupaten yaitu Nabire, dan Jayapura (36,7\% dan 45,2\%). Responden di Kabupaten Nabire, dan Kab./ Kota Jayapura paling banyak tidak bekerja (32,2\%, dan 41,7\%), sedangkan di Kabupaten Jayawijaya proporsi terbanyak adalah petani $(44,4 \%)$. Jika dilihat dari status pernikahan, mayoritas responden di ketiga Kabupaten adalah mempunyai status menikah dengan proporsi terbanyak di Kab./Kota Jayapura (65,5\%).

Pada etnis responden, kebanyakan responden adalah etnis Papua dengan proporsi terbesar adalah di Kabupaten Jayawijaya $(95,6 \%)$. Proporsi serupa terlihat pada etnis 2 generasi di atas responden baik dari pihak Ayah dan pihak Ibu responden.

\section{Pembahasan}

Karakteristik jenis kelamin penderita HIV/AIDS terbanyak pada penelitian ini adalah pada perempuan. Hal ini sesuai dengan penelitian dari Pangaribuan pada tahun 2017 yang menunjukkan 59,1\% ODHA di Sorong Timur berjenis kelamin perempuan(7). Penelitian dari Widayanti pada tahun 2018 juga menyebutkan bahwa penderita HIV di Mimika paling banyak adalah perempuan(8). Namun hal ini berbanding terbalik dengan laporan Ditjen PP dan PL pada tahun 2016, yang menyebutkan bahwa penderita HIV/AIDS terbanyak adalah pada kategori jenis kelamin laki-laki.Hasil survei dari BKKBN juga menyebutkan bahwa satu saja pekerja seks komersial yang terinfeksi oleh HIV dapat menularkan minimal kepada enam laki-laki yang berhubungan seks dengannya(9-11)

Kelompok usia mayoritas dalam penelitian ini adalah pada kelompok usia 17-35 tahun. Hasil penelitian data karakteristik demografi responden kategori usia ini sama dengan data dari Depkes RI pada tahun 2010, yang menyebutkan bahwa kasus HIV/AIDS paling banyak pada usia reproduktif, yaitu pada usia 20-40 tahun. UNAIDS juga melakukan survei pada tahun 2009 dan menyajikan data penderita HIV/AIDS terbanyak di usia 20-40 tahun.Selian itu, Hasil penelitian ini juga memiliki kesamaan dengan laporan dari Ditjen PP dan PLKemenkes RI tahun 2014, persentase kumulatif kasus AIDS tertinggi pada kelompok umur 20-29 tahun (32,9\%), kelompok umur 30-39 tahun (28,5\%), 40-49 tahun (10,7\%), 50-59 tahun(3,4\%), dan 15-19 $(3,1 \%)(9,11)$. Penelitian dari Riski pada tahun 2015 juga menunjukkan hasil bahwa ODHA paling banyak pada kategori usia 20-35 tahun (17).

Tingkat pendidikan responden dalampenelitian ini didapatkan bahwa lulusan SLTA merupakan jumlah terbanyak. Data ini sesuai dengan penelitian dari Hasanah pada tahun 2017 yang menyebutkan bahwa penderita HIV/AIDS terbanyak mempunyai pendidikan lulus SMA. SMA termasuk dalam kategori pendidikan menengah. Pengetahuan tentang kesehatan masih kurang pada tingkat pendidikan ini sehingga belum mengetahui risiko tinggi serta penularan HIV/AIDS(12)

Data karakteristik pekerjaan dalam penelitian ini adalah responden di Kabupaten Nabire, dan Kab./ Kota Jayapura paling banyak tidak bekerja sedangkan di Kabupaten Jayawijaya proporsi terbanyak adalah petani.Kualitas hidup ODHA juga dipengaruhi oleh penghasilan keluarga(13). Penghasilan keluarga yang mencukupi akan mempengaruhi kualitas hidup ODHA. Penghasilan tersebut digunakan untuk memenuhi kebutuhan sehari-hari, biaya perawatan dan pengobatan serta biaya lainnya yang dapat mempengaruhi derajat kesehatan seseorang. Namun apabila tidak mempunyai pekerjaan maka tidak akan mempunyai penghasilan dan tidak dapat melakukan pengobatan HIV/AIDS secara optimal(13-16)'.

Berdasarkan data dari Ditjen PP dan PL Kemenkes RI pada tahun 2014 didapatkan data bahwa jumlah penderita AIDS tertinggi adalah pada ibu rumah tangga dengan jumlah 6.539 kasus. Jumlah kasus tertinggi berikutnya adalah pada wiraswasta dengan julah 6.203 kasus dan diikuti oleh tenaga nonprofessional atau karyawan sebanyak 5.638 kasus, petani atau peternak atau nelayan sebanyak 2.324 
kasus, buruh kasar sebanyak 2.169 kasus, penjaja seks sebesar 2.052 kasus, Pegawai Negeri Sipil sebesar 1.658 kasus dan pada mahasiswa atau anak sekolah sebesar 1.295 kasus(2).

Hasil penelitian menyebutkan bahwa ODHA mayoritas mempunyai status pernikahan menikah. Hal ini sesuai dengan hasil penelitian dari Fadli pada tahiun 2015 yang menyebutkan bahwa 68\% responden risiko tinggi HIV/AIDS sudah menikah. Status sudah menikah menunjukkan bahwa seseorang telah aktif berhubungan seksual dan apabila terdapat perasaan kurang puas terhadap pasangannya maka akan memicu orang tersebut mencari pria idaman lain atau wanita idaman lain. Hal ini dapat menjadi factor risiko penularan HIV/AIDS(17).

Penderita HIV/AIDS dalam penelitian ini paling banyak berasal dari suku etnis asli Papua.Hal ini ini juga berbeda dengan hasil penelitian dari Gunawan, dkk pada tahun 2016 yang menyebutkan bahwa proporsi penderita HIV/AIDS setiap suku adalah sama (50\%), yaitu pada Suku Jawa dan Suku Madura ${ }^{12}$. Suku asli Papua mempunyai proporsi penderita HIV/AIDS yang tinggi dibandingkan dengan suku nonPapua.Hal ini dipengaruhi karena faktor budaya. Penelitian dari Zeth, dkk pada tahunj 2010 menyebutkan bahwa masyarakat Papua mempunyai budaya dan kebiasaan risiko untuk terjangkit AIDS. Risiko penyakit AIDS didapatkan dari perilaku seks bebas dan minum minuman keras. Penelitian dari IPADI juga menyebutkan bahwa $65 \%$ remaja setuju dengan seks pranikah $(6,18)$.

\section{Simpulan dan Saran}

Karakteristik demografi ODHA berdasarkan hasil penelitian adalah bahwa responden di ketiga Kabupaten mayoritas berjenis kelamin perempuan, berusia 17-35 tahun, tingkat pendidikan tamat SLTA, tidak bekerja, sudah menikah dan berasal dari suku etnis asli Papua.Epidemi HIV yang terus meningkat memerlukan semua pihak ikut terlibat secara proaktif dalam penanggulangan HIV/AIDS.Diantaranya adalah memperikan edukasi kepada masyarakat dan kelompok risiko tinggi HIV/AIDS, komunikasi aktif dengan semua pihak terkait serta penyebaran informasi yang bermanfaat tentang HIV/AIDS. Peningkatan kasus HIV/AIDS pada masyarakat usia muda membuat pentingnya peningkatan public awareness mengenai adanya bahaya HIV/AIDS.

\section{Ucapan Terimakasih}

Terima kasih disampaikan kepadaBalai Litbangkes Papua yang telah memberikan bantuan danadari DIPA Balai Litbangkes Papua Tahun 2017 sehingga penelitian ini dapat terselenggara dengan baik.

\section{Daftar Pustaka}

1. Lindayani L, Maryam NNA. Tinjauan sistematis: Efektifitas Palliative Home Care untuk Pasien dengan. 2017;5:8.

2. Ditjen PP \& PL. Laporan Situasi Perkembangan HIV/AIDS Di Indonesia Tahun 2014. Kemenkes RI; 2014.

3. Kemenkes RI. Laporan Situasi Perkembangan HIV-AIDS \& PMS Di Indonesia Januari-Maret 2017. Jakarta: Kemenkes RI; 2017.

4. Butt L. Stigma and HIV/AIDS in Highlands Papua. Pusat Studi Kependudukan-Universitas Cenderawasih and University of Victoria Canada: UNCEN UoV; 2010.

5. Maman S, Abler L, Parker L, Lane T, Chirowodza A, Ntogwisangu J, dkk. A comparison of HIV stigma and discrimination in five international sites: The influence of care and treatment resources in high prevalence settings. Soc Sci Med. Juni 2009;68(12):2271-8.

6. Gunawan YT, Prasetyowati I, Ririanty M. HUBUNGAN KARAKTERISTIK ODHA DENGAN KEJADIAN LOSS TO FOLLOW UP TERAPI ARV DI KABUPATEN JEMBER. :10.

7. Pangaribuan S, Papua Stik. PENGARUH STIGMA DAN DISKRIMINASI ODHA TERHADAP PEMANFAATAN VCT DI DISTRIK SORONG TIMUR KOTA SORONG. Globlal Health Sci. 2017;2(1):5.

8. Widayanti, Mirna et al. Transmisi Heteroseksual Sebagai Faktor Penyebaran CRF01_AE HIV-1 di Mimika Papua. J Health Sci Prev. 2018;2(2):108-12.

9. Kemenkes RI. Pedoman Nasional Tatalaksana Klinis Infeksi HIV dan Terapi Antiretroviral pada orang Dewasa. Jakarta: Kementerian Kesehatan Republik Indonesia Direktorat Jenderal

Pengendalian Penyakit dan Penyehatan Lingkungan; 2011. 
10. BPS B, Kemenkes, ICF International. Indonesia Demographic and Health Survey 2012. Jakarta: BPS, BKKBN. Kemenkes, ICF INternational; 2013 hlm. 544.

11. UNAIDS. AIDS Epidemic Update November 2009. [Internet]. Geneva; Herndon: World Health Organization Stylus Publishing, LLC [distributor; 2010 [dikutip 30 Januari 2019]. Tersedia pada: http://public.ebookcentral.proquest.com/choice/publicfullrecord.aspx?p=589764

12. Widayanti LP, Hidayati S, Lusiana N, Ratodi M. The Correlations Between Student's HIV/AIDS Knowledge and Their Attitude Toward PLWHA. 2018;8.

13. Rayasari, Fitrian. Hubungan Depresi Dan Self Care Practice Dengan Tingkat Fatige Pada Pasien HIV/AIDS Di Pokja HIV/AIDS RSPI Prof. DR. Sulianti Saroso. [Jakarta]: Universitas Indonesia; 2011.

14. Astuti R, Yosep I, Susanti RD. Pengaruh Intervensi SEFT (Spiritual Emotional Freedom Technique) terhadap Penurunan Tingkat Depresi Ibu Rumah Tangga dengan HIV. 2015;3:13.

15. Handajani YS, Djoerban Z, Irawan H. Quality of Life People Living with HIV/AIDS: Outpatient in Kramat 128 Hospital Jakarta. Acta Med Indones. 2012;44(4):7.

16. Oluwagbemiga AE. HIV/AIDS and family support systems: A situation analysis of people living with HIV/AIDS in Lagos State. SAHARA-J J Soc Asp HIVAIDS. November 2007;4(3):668-77.

17. Hasanah RA. Diajukan Sebagai Salah Satu Syarat Mencapai Gelar Ahli Madya Kebidanan Sekolah Tinggi Ilmu Kesehatan Jenderal Ahmad Yani Yogyakarta. [Yogyakarta]: STIKES Jenderal Achmad Yani; 2017.

18. Zeth AHM, Asdie AH, Mukti AG, Mansoden J. PERILAKU DAN RISIKO PENYAKIT HIV-AIDS DI MASYARAKAT PAPUA STUDI PENGEMBANGAN MODEL LOKAL KEBIJAKAN HIV-AIDS. AIDS . :14. 